\title{
Fast track to the labour market? Experiences of learning in an active labour market policy measure for migrant teachers in Sweden
}

\author{
Elin Ennerberg ${ }^{1}$ (D)
}

Received: 17 November 2019 / Accepted: 20 January 2021 / Published online: 13 February 2021

(c) The Author(s) 2021

\begin{abstract}
This article analyses the case of a Swedish so-called "fast-track" programme for newly arrived migrant teachers with the use of a conceptual model of lifelong learning dimensions (Boyadjieva \& Ilieva-Trichkova, 2016). The material is based on individual and focus group interviews with individual participants, public employment officers and university teachers. While some aspects of the course can be seen as transformative and allowing for intrinsic learning, the participants' need for work often overshadowed more ambitious course goals. Nevertheless, the course provides participants with the opportunity to reflect on new aspects of teaching and broader societal values.
\end{abstract}

Keywords Migration · Lifelong learning · Activation · Active labour market policy · Transitions

\section{Résumé}

Une voie rapide vers le marché du travail ? Expériences d'apprentissage dans le cadre d'une mesure de politique active du marché du travail pour les enseignant·e's migrant·e·s en Suède Cet article analyse le cas d'un programme suédois dit "fast-track" pour les enseignant·e.s migrant·e.s nouvellement arrivée.e.s en utilisant un modèle conceptuel des dimensions de l'apprentissage tout au long de la vie (Boyadjieva \& Ilieva-Trichkova, 2016). Le matériel est basé sur des entretiens individuels et de groupes de discussion avec les participant·e.s, les agent.e.s de l'emploi public et les enseignant-e.s universitaires. Bien que certains aspects du cours puissent être considérés comme transformatifs et permettant un apprentissage intrinsèque, le besoin de travail des participant·e·s a souvent éclipsé les objectifs plus ambitieux du cours. Néanmoins, le cours donne aux participant·e-s l'occasion de réfléchir à de nouveaux aspects de l'enseignement et à des valeurs sociétales plus larges.

Elin Ennerberg

elin.ennerberg@mau.se

1 Department for Society, Culture and Identity, Malmö University, Malmö, Sweden 


\section{Zusammenfassung}

Schneller Weg in den Arbeitsmarkt? Lernerfahrungen in einer aktiven arbeitsmarktpolitischen Maßnahme für zugewanderte Lehrer in Schweden Dieser Artikel analysiert den Fall eines schwedischen sogenannten "Fast-Track"-Programms für neu angekommene Lehrer mit Migrationshintergrund unter Verwendung eines konzeptionellen Modells von Dimensionen des lebenslangen Lernens (Boyadjieva \& Ilieva-Trichkova, 2016). Das Material basiert auf Einzel- und Fokusgruppeninterviews mit einzelnen Teilnehmern, öffentlichen Arbeitsvermittlern und Hochschullehrern. Während einige Aspekte des Kurses als transformativ angesehen werden können und intrinsisches Lernen ermöglichen, überschattete das Bedürfnis der Teilnehmer nach Arbeit oft die ehrgeizigeren Kursziele. Nichtsdestotrotz bietet der Kurs den Teilnehmern die Möglichkeit, über neue Aspekte der Lehre und weiter gefasste gesellschaftliche Werte zu reflektieren.

\section{Resumen}

¿Vía rápida al mercado laboral? Experiencias de aprendizaje en una medida de política activa del mercado laboral para los maestros migrantes en Suecia En este artículo se analiza el caso de un programa sueco denominado "de vía rápida" para los maestros migrantes recién llegados, basado en un modelo conceptual de dimensiones de aprendizaje a lo largo de toda la vida (Boyadjieva \& Ilieva-Trichkova, 2016). El material se basa en entrevistas individuales y en grupos de discusión con los participantes, funcionarios públicos y profesorado universitario. Si bien algunos aspectos del curso pueden considerarse transformadores y favorecedores de un aprendizaje intrínseco, la necesidad de trabajo de los participantes a menudo eclipsó los objetivos más ambiciosos del curso. No obstante, el curso brinda a los participantes la oportunidad de reflexionar sobre nuevos aspectos de la enseñanza y valores sociales más amplios.

\section{Introduction}

Labour market measures aimed at migrants often focus on the political goals of fast labour market entry. Following the great influx of migrants into Europe after 2015, integration into the labour market has been singled out as a particularly pressing problem (Fóti, 2019). At the same time, migration has for a number of decades been seen as a potential solution to Europe's aging population, with migrants expected to fill the potential labour shortage (Johnson \& Zimmermann, 2008). The need for labour power means that the integration of migrants into the labour market could be seen as a problem in terms of matching individuals with certain occupations or potentially directing individuals to certain occupations. This would imply a shift in focus from citizenship and integration measures (Goodman, 2010; Mouritsen et al., 2019) towards providing labour market measures with the aim of (re-) skilling or updating individuals' skills in relation to the needs of the labour market of the host society. In practice, the use of migrants' professional skills and experience necessitates a more qualified and nuanced response from career guidance counsellors or 
employment officers in order for migrants to navigate local labour market demands, language learning, and formal and informal requirements for entering various professions. In this article, I will use the case of Sweden to discuss one such labour market measure: one that expressly aims to use migrant labour power to fill current shortages in the national educational system.

Before stricter regulations in relation to citizenship and border controls were introduced (Dahlstedt \& Neergaard, 2019), Sweden was one of the countries receiving many asylum applications in the light of the increased migration to Europe in 2014-2015. ${ }^{1}$ With its long history of labour market policy directed towards migrants (see, for example, Bevelander \& Lundh, 2007), newly arrived migrants to Sweden have, since 2010, been expected to take part in two-year introduction programmes organised by the Swedish Public Employment Service. These programmes focus on language learning, civic orientation and labour market activities (Ennerberg, 2020; Wikström \& Ahnlund, 2018). Building upon these existing measures, the Swedish government in 2014 announced that a number of vocational fast tracks would be initiated to allow newly arrived migrants to enter professions where employer organisations and labour unions agreed there was a significant labour shortage. These fast tracks were to include validation of skills, (vocational) language learning and labour market contacts. In essence, these measures can be seen as a move to bridge a national need for labour power with the need to integrate migrants into the local labour market.

The fast track for teachers and preschool teachers was introduced in 2016 and was established in cooperation with the following social partners: the Swedish Teachers' Union, the National Union of Teachers, Swedish Association of Local Authorities and Regions, and the Employers' Organisation for the Swedish Service Sector. The measure was coordinated by the Swedish Public Employment Service, with the development of the course being delegated to six Swedish universities. Despite a political rhetoric emphasising fast labour market entry, the actual route to becoming an accredited teacher is relatively long and encompasses both Swedish language requirements and an accreditation process where past experience and academic transcripts are validated. For many participants, further complementary university studies are needed to gain accreditation.

The fast track for teachers and pre-school teachers was specifically aimed at newly arrived migrants who speak Arabic, and either currently participate in the Swedish language introduction programme, or who have within the last 12 months finished this introduction. During the 26 weeks of the programme, the participants weekly spent two days at the university learning about the Swedish educational system and one day doing Swedish language learning, and two days doing work experience in a school. The fast-track course had no Swedish language requirement, meaning that the level of Swedish varied among participants (Arbetsförmedlingen, 2017).

\footnotetext{
1 Statistics from the Swedish Migration Agency shows that asylum applications peaked at 162877 individual applications in 2015, compared to 28939 the year after when stricter regulations had been implemented (Migrationsverket, 2019).
} 
The fast-track course is formally a labour market measure coordinated by the Public Employment Service and can thus be interpreted as a measure that focuses primarily on activating individuals. At the same time, the actual content can be compared to an adult education course, focusing both on learning about the Swedish school system and on (re-)developing professional competencies. The aim of this paper is to consider whether this type of measure can be seen primarily as an activation measure or as a lifelong learning measure that enhances individual autonomy. While this is important in terms of understanding the consequences of these types of initiatives, it is also useful to consider whether an analysis can clarify the links between activation and lifelong learning theoretically. Activation literature often emphasises instrumental and coercive aspects of labour market policy, but depending on the context, more positive aspects related to lifelong learning might be compatible with activation policies. In the article, my starting point is the following research question:

How do migrants experience the different demands and expectations of participating in a labour market course?

How do the individuals' experiences fit into a human capability approach of lifelong learning?

To answer the research question, I use qualitative data to analyse the early stages of individuals' potential path to employment in the teaching "fast track" and discuss the challenges associated with the education and work experiences involved in the measure.

In the article, my starting point is a conceptual model of lifelong learning dimensions (Boyadjieva \& Ilieva-Trichkova, 2016).

\section{Migrants in the labour market}

A traditional life course for an individual contained a relatively stable and predictable path: individuals moved from education to work, maintained a certain career and then reached retirement. In recent decades, this previously stable life course has changed, as the movements in and out of education and work have become both more unpredictable and, for many individuals, more numerous (Bovenberg, 2007). Politically, increased flexibility has been hailed as positive, in allowing individuals to be able to change careers and re-train. Moreover, organisations such as the EU and the OECD promoted strategies of lifelong learning that may accommodate certain educational or financial support for individuals. These initiatives increasingly focused on maintaining an employable workforce (Nicoll \& Fejes, 2011), thus partly replacing the traditions of bildung and adult education (Fejes \& Nylander, 2019). The previously more predictable "life cycle" has thus, to a certain extent, been replaced by an increased flexibility in how individuals' careers are shaped through different choices, as well as forced transitions, rather than a one-time choice. Transitions are also seen as potentially leading to new opportunities, both in terms of personal and of professional life (Evans \& Biasin, 2017). Nevertheless, the literature on 
transitions tends to highlight individual trajectories in the context of national labour markets and educational systems (although, see Colley, 2010).

Recent studies on migrants entering European labour markets have focused on migrants' difficulties in finding a role in the labour market due to their status as migrants. In a recent German study, some of these difficulties have been found to be alleviated by the use of social capital. For example, one might gain employment by "bridging" social contacts who could assist in finding one work at the appropriate skills level (Gericke et al., 2018). Other scholars have focused on the importance of understanding migrants' social networks, particularly family relationships and migrant communities as important for their career development (Campion, 2018). Difficulties for migrants in terms of employment also include a lack of information about the local labour market, limited language skills and difficulties in validating formal qualifications (Bimrose \& McNair, 2011; Yakushko et al., 2008). Choice in relation to career advice is thus likely to be more constrained than for other groups, leading to calls for increased advocacy in career advice for migrants. (Bimrose \& McNair, 2011). Mešić et al. (2019) argue that study associations can provide a model for civil society actors to support migrants through focusing on the needs of individual migrants, for example, by providing a social network.

\section{Lifelong learning and Active Labour Market Policy}

Career transitions are events that concern individuals in different parts of society. For individuals in a more stable labour market position, career change can be framed primarily in terms of choice relating to, for example, personal interest or career opportunities, while individuals with a more uncertain labour market position may experience career change less as a choice and more as a necessity (Ecclestone et al., 2010). Attention to these processes have become more urgent in recent decades due to the expectations on the individual to engage in choice and to shape one's own individual trajectory (Giddens, 1991; Beck \& Beck-Gernsheim, 2002). As a result, individuals' educational and career biographies have become more flexible and no longer follow a stable life course (Tomlinson, 2013, p. 112).

Political discourses of lifelong learning refer to the increasing need for individuals to (re-) enter training and education at different points of their lifecourse due to changing labour markets. However, critics have argued that lifelong learning, first and foremost, supports a neoliberal vision of educating individuals to suit the shifting demands of the market (Crowther, 2004). Here, lifelong learning becomes primarily an individual "duty" rather than an opportunity for learning (Biesta, 2006). Lifelong learning often encompasses adult education courses. However, as we will see, the premises for lifelong learning can also be related to active labour market initiatives and training.

Active labour market policies (ALMP) have a long history in Sweden (Meidner, 1998). They have more recently been used in many European countries both to facilitate economic growth and to provide more socially inclusive labour markets (Bonoli, 2012; Morel et al., 2012). While active labour market policies can include various supportive measures, such as labour market education, "activation" policies can also include more 
restrictive measures, such as sanctions, benefits conditionality and emphasis on quick labour market entry (Dwyer, 2004; Lødemel \& Moreira, 2014). In its more supportive forms, activation or ALMP could be seen as a complement to or a form of adult education for individuals in need of re-training.

To consider to what extent these types of policies can be viewed as part of lifelong learning initiatives in line with a capability approach is particularly relevant for newly arrived migrants. The language training, potential validation or re-training measures prior to participation in more general education initiatives can take up a substantial amount of time for this group. Early career guidance that takes account of individuals' choices and opportunities may therefore be essential within the framework of introduction programmes or similar activation services because participation in these measures can shape the future career trajectories of individuals (Newman et al., 2018). Consequently, the particular policy mix and how it is applied in practice is important to understand if it is primarily restrictive or enabling.

In this paper, I use a theoretical model of lifelong learning dimensions in a capability approach to consider if an active labour market measure such as the teaching fast track can fit this model. Boyadjieva and Ilieva-Trichkova (2016) take Sen's capability approach as a starting point to consider how lifelong learning can take account of individual agency and choice in a way that is positive for society and for individual development. Compared to other studies that emphasise human capital following Becker (1993)—who emphasises how increased knowledge and skills can be related to an increase in productivity and earnings - the adapted model attempts to capture other dimensions of learning, such as the transformative potential of learning for individuals. Moreover, from a societal perspective not only economic productivity gains but also more social dimensions are considered.

In a simplified version of the model, the following dimensions are taken into account:

As seen in the table, Boyadjieva and Ilieva-Trichkova acknowledge that lifelong learning needs to be considered in different dimensions in order to take account of both the individual influence and the societal influence. The development of lifelong learning seen through the different levels of instrumental, intrinsic and transformative/ empowering character can thus be used to analyse how a particular educational initiative can be aligned with the different goals.

It is also useful to consider the table in relation to the literature on activation, that is, to see how studies on active labour market policy initiatives can be understood in relation to a model focused on primarily adult education as lifelong learning. Considering the key aspects of active labour market policy, we can see that the instrumental goalsparticularly employability, promoting economic growth and human capital development-clearly fit this framework. In order to consider whether this type of policy can also be seen as incorporating the other dimensions, the concepts of intrinsic and transformative lifelong learning will be used to analyse the material. 


\section{Methods}

\section{Participants}

This study was carried out over six months and followed one cohort of teachers participating in the course on how to become certified teachers in Sweden. The material collected includes observations, focus group interviews with participants and semistructured interviews with course participants. A total of 16 course participants were interviewed at the beginning of the course through four focus group interviews, consisting of four participants in each group. Two of the focus group interviews were held with an interpreter, translating between Arabic and Swedish. At the end of the course period, final interviews were carried out with 18 course participants All of the final interviews were individual interviews, apart from two interviews where I interviewed two participants together. Moreover, seven university teachers (including two course coordinators) and two employment officers were interviewed over the 26 weeks. Note that as some of the participants were the same in the total number of interviewees is 33 .

\section{Procedure}

Interviews and focus groups were chosen as a method in order to understand the viewpoints of participants, but also to allow for different discussions among the individuals (Kvale, 2007). All interviews were audio recorded and transcribed.

Apart from the aforementioned interviews, a large number of informal interviews took place with participants throughout the course, that is, before, during and after university teaching, and at some participants' work experience placements. Only some of these interviews were audio recorded and transcribed. Although these interviews are not directly used in this article's material, the information therein has nonetheless informed the research process, not least as interview respondents in the final interviews often refer to previous more informal conversations I had with participants over the 26 weeks of the course. Interviews were held in English or Swedish, apart from the two focus group interviews mentioned above where I used an Arabic-speaking interpreter. The use of language interpreter may have affected some of the data, as there is a risk that the interpreter brings certain pre-conceived knowledge of the topic to the interpretation. (Bergen, 2018). The possibility to follow the group over time and thereby be able to clarify certain issues with participants may however have reduced this risk, particularly as participants were increasingly able to talk to me in Swedish. While the citations have been edited for grammatical errors I have endeavoured to limit this editing as much as possible in order to capture the individual expression of the informants.

To protect the identity of respondents, I have elected not to provide information regarding their age, though I occasionally mention age categories. However, the gender of the course participants is referred to as this was an important aspect of the material. In line with ethical guidelines regarding consent and data collection 
(Vetenskapsrådet, 2017), all participants were informed that participation in the study was voluntary and that they could withdraw at any time. The participants were also informed of the regulations guiding consent and storing of data. Two of the migrant teachers in the class chose not to participate. While two individuals did choose not to participate, it is still possible that due to their position as students at the university, some individuals might have felt some pressure to participate. Moreover, in the early stages of research, I received some questions regarding my role in the classroom, for example about the organization of the course or the process of teacher accreditation. However, many individuals later approached me with different issues they thought deserved my attention from a research point-of-view, and they also commented on the value of being able to express their thoughts on the set-up of the course.

\section{Analyses}

Preliminary data analysis started during the fieldwork period when certain themes became more interesting. In one way, these themes guided the fieldwork to the extent that these issues were given closer attention in the classroom and in interviews with participants. After the fieldwork period, the notes and interview material were transferred to Nvivo 12 and coded in line with a thematic analysis (DeCuir-Gunby et al., 2011). The data analysis was conducted in an abductive manner, moving back and forth between the empirical data and theoretical assumptions (Tavory \& Timmermans, 2014). An initial thematic analysis was developed by summarising the most prominent themes found in the material and included themes such as progression, employability, and future plans. In a second step, moving back and forth between the data and the theory, the themes were then re-conceptualised and considered in relation to the model of lifelong learning dimensions. Apart from the levels in the model, the theme of choice has been included as a way of highlighting the potential difficulty in achieving transformative learning in circumstances when individuals do not freely choose to participate in learning activities.

\section{Results}

\section{Choice}

One of the dilemmas in terms of guiding individuals towards the labour market is to ensure individual cooperation while simultaneously enforcing participation, that is, motivating individuals to participate in an activity they themselves have chosen to take part in. While choice can be presumed as implicit in relation to lifelong learning in the capability approach, this is thus not the case in activation policies generally, but needs to be considered in relation to each policy initiative. In activation policies, this issue is often referred to as benefits conditionality based on participation. This issue is considered differently by the various actors 
-from their perspective either as educators at a higher education institute or as representatives of the Swedish Public Employment Service.

"That's very tricky for us, if someone, for example, says no to a cleaning job. And it can happen that one employment officer thinks that's ok, because the other route [towards teacher certification] is very clear. But work always comes first. But we don't always agree on the evaluation "That's not for teachers". No, but they are in this programme because they don't have a job." (Employment officer, R8).

Herein, we can clearly see the employability perspective put forward by the employment officer. In this instance, this particular activation measure seems far from a capability perspective, offering individuals any choice in regards to education routes. However, later in the interview, it becomes clear that this picture may also be more nuanced:

Then they ask, 'Why should I choose this and drop out of Swedish for migrants? If I choose to study Swedish, then I can apply for ULV [a validation course for teachers who have finished Swedish studies] later on. Why should I choose this?' There's no good answer to that question. But it's important to tell them that this is one route; it's not a forced route. The Public Employment Service doesn't force them to do this, but it's an offer. Some might long to be in an educational environment. Others think that 'No, I'm really determined to study Swedish.' Then that's a different route.

(Employment officer, R8).

Here, we see that, at least for this group of migrants, there is an understanding that individuals' career and educational trajectories can differ, thus implying that individuals have some latitude for choosing the preferred way towards becoming a teacher.

At the same time, there is room for negotiation and interpretation, allowing both individual employment officers and individuals to make their case for staying in a more suitable activity even if other alternatives, such as un-skilled work, become available. The importance of enabling individuals or groups to achieve certain social mobility can be placed more in line with the field of transformative lifelong learning in the model - suggesting that individuals can use the course to achieve a higher position in the labour market.

However, different accounts of individuals sometimes clash with this perspective of being able to independently choose the most suitable route:

The employment officer said, 'There's this fast track course for teachers, and you need to go there.' I said, 'I can't. I've only reached Swedish level B. I can't.' But they said, 'There are teachers there who speak Arabic; it's ok. (Male course participant, R7).

Despite his low Swedish skills and desire to continue his Swedish studies, the fast-track course was seen by employment officers as the most appropriate route for this participant. Many participants revealed that they would have rather 
participated in Swedish studies, but they also believed that, as the fast-track course was recommended by the Public Employment Service, it would be inherently useful for them in terms of leading to a job or having an advantage in the labour market.

\section{Instrumental learning}

In terms of the concept of instrumental learning, many of the participants themselves focused on the importance of the education leading to employment. Some of the interviewed female participants were hesitant to take the longer route to getting teacher accreditation. Instead, they were weighing up the possibility of working in the same occupational area, but at a lower level:

There's a short way and a long way. If we want to develop and become better, that's the long way, through Swedish and higher education. If we want to take a shorter way, we can, for example, apply to childcare positions, work as a teaching assistant, where you don't need a teaching certificate. But still, you will be working with children and helping children. Me, I will do the best I can. I will try to finish Swedish and validate my degree. But still, I will also apply to childcare courses and whatever comes, I will go that way. But both ways take me to the same job - working with children. (Female course participant, R2, final interview).

This female participant thus positions herself as a person aiming to work with children, though not necessarily as a teacher, even if this would have been the preferable option. The need to find a job quickly, which was formulated by many of the participants, was also discussed by male interviewees. However, entering the labour market at a lower level was also seen as more problematic for some of the male participants:

We have this long experience, but we might get this offer. Temporary employment, yes we can work in temporary employment, but I don't think it's correct at all. (Male course participant, R3, final interview).

With much experience as a teacher, the above interviewee considers the option of starting as a temporary teacher as problematic. In an earlier interview, the same participant also related this to the necessity of having a permanent job in order to get easier access to housing. Here, systemic or structural discriminatory practices are thus raised, as the participant suggests that there is an element of social injustice in not being able to obtain a permanent job, despite having the knowledge and competence required for the labour market.

\section{Intrinsic learning}

In the model of lifelong learning, intrinsic learning is defined in terms of "valuing and acquiring knowledge for its own sake" on an individual level. However, on a societal level it also includes "validation of different types of knowledge" and 
"legitimatization of values in society". The course content contains many aspects of the Swedish system regarding, in particular, values related to the Swedish school system. One of the university teachers, who also has a migration background, explains how values take up an important part of the course:

So, you imagine that they think of others who have the same background, who understand their values, and understand their culture. And they think with them, and they have gone the same route. That's what I mean. So, Fast Track for me is not just about ... well, they want to get teacher credentials, absolutely, they want the accreditation. And what they really need is language first and foremost, but they need to understand the culture, the society and the values, and to discuss it with someone; they really need it. (University teacher, 1).

The emphasis on the discussion of different value systems and how to interpret a new culture is something that can be related to the importance of legitimizing different values at a societal level:

And now there is a great challenge facing us, we as teachers. We are facing a notable problem here: how to shift our minds and behaviour to adjust and adapt ourselves into these programmes. And to be teachers in the system. [laughs] So, it is a challenge for the participants. So, they may make it, also they may not. It is a matter of whether you accept it or if you ... And to be a teacher, it's really to love the kids as if they are your own kids. So, it's a big challenge... (Male participant, 5).

The account of this participant supports the teacher's view above of the importance of reflection in relation to these values, and perhaps challenging and developing one's own pre-conceptions based on teaching.

The emphasis on values can also be considered in relation to how the course content is presented for the participants, involving many group exercises and discussions, rather than clearly presented lectures and tests. However, this way of teaching is also seen as problematic by some of the participants:

First, I thought that the course would be a lot better, but there's no clear and specific course credits. Most of the course is just talking and discussions. I don't think we get much from it; it's just a waste of time. It's a great disadvantage. We want to have clear and specific goals so that we can learn. And we would also like to have tests and exams so that we can be evaluated and so that we know what we need to be able to teach. (Male course participant 3 , focus group).

Similarly, some of the participants argued for clearer course content and goals where individuals could be tested in terms of acquired knowledge and progress. Here, the value of acquiring knowledge for its own sake can be seen as clashing with the participant's sense of time urgency, where the goal of entering the course is more related to instrumental knowledge than the intrinsic values.

Moreover, a potential clash can be seen between the aim of discussing Swedish values in relation to school and the aim to utilize and validate participants' 
previous knowledge. While the information and practical work experience was seen as beneficial in terms of understanding the system better, many participants also expressed a sense of frustration that they were still far from being accredited teachers:

It takes too long. I can't work as the main teacher. OK. I know that I need more time, and I have to study more, work with the language. Yes. But I can work as an assistant teacher, or translate to Arabic. I can help students; I know English, I know Arabic. I can translate to English as well. That's also great. (Female course participant, 6).

The desire for formal qualifications also concerned other aspects of the course. The necessity of using the time well to avoid further delays to enter the labour market was formulated by many of the individuals taking part in the course. The wait for residence permit, language studies and participation in other labour market activities meant that many expressed a clearly formulated urgency, where they were pressed for time to take up their careers again. In a sense, the participants' vulnerable position in the labour market thus somewhat foreshadowed their willingness to engage with the more intrinsic learning goals of the course. In this sense, the need to experience clear progress can be seen in this desire for formal qualifications that would enable the individuals to seem to be heading to a particular destination.

\section{Transformative learning}

The transformative or empowering aspects of lifelong learning are related to aspects such as personality development, empowerment and on a societal level, (re)distributive in the sense of "facilitating social group mobility... and the ability of different groups to organize and express their interests".

For some participants in the course, the ability to learn more about Swedish society and schools can be interpreted as a form of personality development:

There are many differences between Swedish schools and Syrian schools. In school law and values, there is some dissimilarity. There is an enormous difference. I have to change, and it takes a lot of time. It takes a long time to understand laws and understand everything concerning school. It will take a lot of my time, a lot of time. (Female participant, 4).

The experience of participating in the course can thus be seen as a challenge in terms of feeling the expressed need to change one's professional behaviour in order to fit in to a new and required order. In this sense, transformative learning can be seen as not inherently positive, but also as a required step to be able to find employment. On the other hand, this participant in later interviews also underlines that some of these lessons lead to new insights in relation not only to professional practices but also to societal values:

These are good thoughts. And they are new thoughts for us. In Syria, women and men, they don't have equal rights. Women are more dependent on their men. And I think that is the reason for this is economics. Here in Sweden, 
there is a difference here. Independence. Women have independence; and children, when they turn 18 , they have independence financially. So, there is a difference. But that's a good thing ... My daughter likes to play soccer with guys. If this situation were to happen in Syria, it would be 'No, you don't get to play football'. Everyone would think she's a boy... But here it's 'Okay. Try. Try everything.' So... (Female participant, 4).

The discussions relating to gender in Swedish schools that have been part of the course material are thus used by this participant not only to better understand society at large but also to interpret how these issues should be managed in relation to her own children, who are at school in Sweden. At the same time, gender-related issues are seen as obstacles for some of the female participants who wear a veil for religious and self-expression purposes. One participant reflects on a previous discussion she has had with a foreign-born teacher employed at a Swedish school:

He said, 'Frankly, and I am sorry to say that, you are Muslim. You have a veil and this will be an extra problem for you, especially here with teenagers.' I said, 'Okay, this is what I needed to hear. I can't do that.' Because I had a family with so much stress, I can't handle stress here, much stress for eight hours. Work is eight hours and the rest of the day is stressful... How can I live? That's why. When I think about work experience, I think it will be easier, but if I think about "I will be a teacher. I will have the same problems." And teenagers, we can do nothing about them. Sorry to say that. And it's very hard to control them. And maybe they can have comments like "You are coming from bla, bla, bla. And you are ..." So, I can't do anything about that. I can't talk to them about that. I can't discuss it. Maybe they will say something. I can't ignore them, or there will be a problem. That's why. For me, this is what I'm thinking. (Female course participant 7, focus group interview).

For women in the group (with or without a veil), discussions of experiencing negative or discriminatory comments from colleagues or students leads them to reflect upon their own willingness to enter the system. Though the discussion focuses on a lack of respect and a lack of regulations to support teachers, it also centres on personal feelings of well-being and the necessity to find a job that they can feel happy with in an already pressured situation. However, the same female participant considers the issue slightly differently in the final interview, approximately six months later:

And [the other course participants] are supportive. They say, 'Ok, you have the best level of us. You can do this, you can do this!' They want me to do this. They say, 'you have a shorter way [to getting accreditation].' I say, 'Ok, I can do it for you' [...] For me also, of course, but for them also. I want to do something. They want to do something; but it's when they think about language, the course, they feel a little bit depressed. But then we say, 'OK, we can do that.' Now we are proud of each other. 'We can do that, we should talk to someone, we can work.' Even like substitutes, assistants or something. We can do that. (Female participant, 7). 
Completing the course with the other participants can be seen as providing a new social network of contacts who support each other and provide something akin to group identity. In this context, the problems of wearing a veil are seen as obstacles that can be overcome, as the goals of inspiring each other and setting a good example for the other participants in the group are more important. This could be seen as a potential example of the possibilities for different groups to organize, thus in line with the transformative/empowering influences on a societal level.

\section{Discussion}

In the analysis above, I discussed the different aspects of choice, instrumental learning, intrinsic learning and transformative/empowering learning. The aim of the paper was to consider how the migrants participating in the course experienced demands and expectations, but also how these experiences can be analysed in relation to a human capability approach of lifelong learning.

In the "Results" section, I considered different accounts of how migrant teachers participating in the course have experienced the labour market measures at hand. From these accounts, we can see that there is a wide variety of responses to the first research question. The participants' views of the course express both positive and negative sentiments. Moreover, these can vary over time as the individuals make sense of the education and the work experience. As well as discussing the content of the course and the potential of the course in terms of finding future employment or continuing education, participants also discuss the more social aspects of the education, for example the importance of developing both friendships and a professional network. At the same time, the overarching theme, although sometimes subtle, in many of the accounts is the marginal labour market position of the individuals, in which the content of the course often matters less than the overarching ambition of being able to use the course as a means to enter the labour market.

This vulnerable position is important to consider when answering the second research question, that is, whether this active labour market policy measure can be considered as aligned with lifelong learning from a capability perspective. The first issue in terms of activation policies relates to the question of conditionality. For individuals outside of the Swedish labour market, a certain amount of benefits conditionality and active participation has been expected, and remains so in relation to this course. Nevertheless, here it is unclear to what extent participants can opt-out of this particular measure and choose other routes in order to follow their desired career trajectory. For the group of newly arrived migrants, especially those individuals with lower Swedish language skills, the recommendation to participate 
in one particular measure may appear more as a requirement than as an offer of one of many potential routes.

In terms of the instrumental character of influence, this level of the model can be seen as compatible with most activation policy in terms of increasing individual employability and economic growth. Interestingly, when considering the other levels of the model, it becomes difficult to separate the issue of employability from the other dimensions. For example, while different participants express a view that can be seen as aligned with a more intrinsic or transformative learning model, such as emphasising the need to re-consider previously upheld ideals and values, these ambitions were also connected to the goal of future employability. For others, employability was the core value of the course, leading to a certain clash with the ideals of university teachers to engage students in potentially more ambitious study objects more related to intrinsic learning goals. This suggests that although a specific course content can be ambitious in scope and learning objectives, in one way this can be overshadowed by the institutional conditions of the education.

Finally, the societal potential of facilitating social group mobility can be seen as one of the goals of the fast track courses, which aims to facilitate work in relevant work areas rather than in lower-level employment. Naturally, this article cannot evaluate whether this goal has been achieved. However, it seems from some of the accounts that the professional networks created through this type of more specific ALMP can be one way of facilitating the development of potential organization of joint group interests in line with the model. The access to social networks that can be found in study associations (cf Mešić et al., 2019) could be seen in this type of ALMP course as well. Moreover, the individuals' professional status and background as teachers can be seen as facilitating their commitment to the course. In this sense, the importance of social networks as discussed by other authors (Campion 2018; Gericke et al., 2018) may also be built up in a structured way through this type of (re-)professionalization courses.

At the same time, it should be considered whether this lifelong learning ambition is in line with the participants' goals. For many, the quality of the course and the potential of lifelong learning is, at this stage of their career trajectory, perhaps less important than clear and structured routes into employment for them to reach a more permanent labour market position. Similar to Bimrose and McNair's (2011) argument, it seems as if more structured guidance is often requested by individual participants, whose main concern is to find the most certain route to employment. To summarise, it appears that this initiative can be seen as fitting into the lifelong learning model presented above, through providing individuals with an opportunity to participate in ALMP with the potential to take part in more ambitious learning initiatives (Tables 1, 2). 


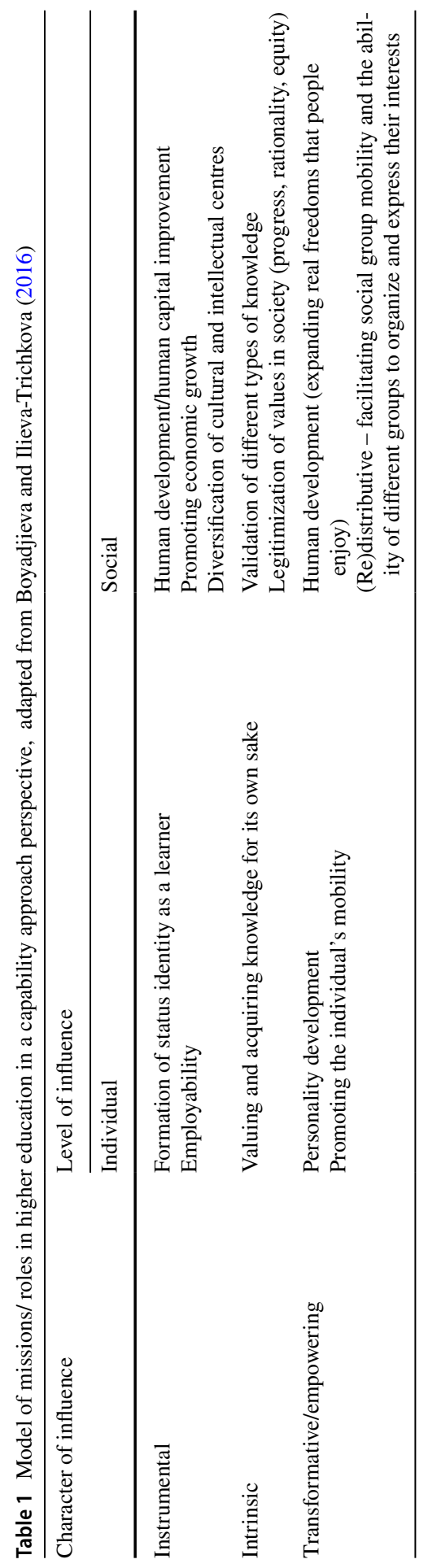


Table 2 Interview participants

\begin{tabular}{lll}
\hline & Gender & Total \\
\hline Focus group interviews & 5 men, 9 women & 16 individuals \\
Individual interviews & 6 men, 12 women & 18 individuals \\
Teachers & 3 men, 4 women & 7 individuals \\
Employment officers & 2 women & 2 individuals \\
\hline
\end{tabular}

8 of these individuals also participated in the focus group interviews and were thus interviewed twice

Funding Open access funding provided by Malmö University.

Open Access This article is licensed under a Creative Commons Attribution 4.0 International License, which permits use, sharing, adaptation, distribution and reproduction in any medium or format, as long as you give appropriate credit to the original author(s) and the source, provide a link to the Creative Commons licence, and indicate if changes were made. The images or other third party material in this article are included in the article's Creative Commons licence, unless indicated otherwise in a credit line to the material. If material is not included in the article's Creative Commons licence and your intended use is not permitted by statutory regulation or exceeds the permitted use, you will need to obtain permission directly from the copyright holder. To view a copy of this licence, visit http://creativecommons.org/licen ses/by/4.0/.

\section{References}

Arbetsförmedlingen. (2017). Snabbspår för lärare och förskollärare [Fast-track for teachers and preschool teachers].

Beck, U., \& Beck-Gernsheim, E. (2002). Individualization: Institutionalized individualism and its social and political consequences. SAGE.

Becker, G. (1993) [1964]. Human capital: A theoretical and empirical analysis with special reference to education. The University of Chicago Press.

Bergen, N. (2018). Narrative depictions of working with language interpreters in cross-language qualitative research. International Journal of Qualitative Methods, 17(1), 1-11. https://doi. org/10.1177/1609406918812301.

Bevelander, P., \& Lundh, C. (2007). Arbetskraftsinvandring och flyktingars arbetsmarknadsintegration [Labour market migration and the labour market integration of refugees]. In G. Alsmark, T. Kallehave, \& B. Moldenhawer (Eds.), Migration och tillhörighet. Inklusions- och exklusionsprocesser $i$ Skandinavien [Migration and belonging. Inclusion and exclusion processer in Scandinavia]. Makadam.

Biesta, G. (2006). What's the point of lifelong learning if lifelong learning has no point? On the democratic deficit of policies for lifelong learning. European Educational Research Journal, 5(3-4), 169-180. https://doi.org/10.2304/eerj.2006.5.3.169.

Bimrose, J., \& McNair, S. (2011). Career support for migrants: Transformation or adaptation? Journal of Vocational Behavior, 78(3), 325-333. https://doi.org/10.1016/j.jvb.2011.03.012.

Bonoli, G. (2012). Active labour market policy and social investment: A changing relationship. In N. Morel, B. Palier, \& J. Palme (Eds.), Towards a social investment welfare state? Ideas, policies and challenges. Policy Press.

Bovenberg, A. (2007). The Life-Course perspective and social policies. OECD Publishing.

Boyadjieva, P., \& Ilieva-Trichkova, P. (2016). Rethinking missions and values of higher education: Insights from the capability approach and the institutional perspective. In R. Pritchard \& J. Williams (Eds.), Positioning Higher Education Institutions: From Here to There (pp. 41-62). Sense. 
Campion, E. D. (2018). The career adaptive refugee: Exploring the structural and personal barriers to refugee resettlement. Journal of Vocational Behavior, 105, 6-16. https://doi.org/10.1016/j. jvb.2017.10.008.

Colley, H. (2010). Time in learning transitions through the lifecourse: A feminist perspective. In K. Ecclestone, G. Biesta, \& M. Hughes (Eds.), Transitions and Learning through the Lifecourse. Routledge.

Crowther, J. (2004). 'In and against' lifelong learning: Flexibility and the corrosion of character. International Journal of Lifelong Education, 23(2), 125-136. https://doi.org/10.1080/02601 37042000184174.

Dahlstedt, M., \& Neergaard, A. (2019). Crisis of solidarity? Changing welfare and migration regimes in Sweden. Critical Sociology, 45(1), 121-135. https://doi.org/10.1177/0896920516675204.

DeCuir-Gunby, J. T., Marshall, P. L., \& McCulloch, A. W. (2011). Developing and using a codebook for the analysis of interview data: An example from a professional development Research Project. Field Methods, 23(2), 136-155. https://doi.org/10.1177/1525822X10388468.

Dwyer, P. (2004). Creeping conditionality in the UK: From welfare rights to conditional entitlements? The Canadian Journal of Sociology, 29(2), 265-287.

Ecclestone, K., Biesta, G., \& Hughes, M. (2010). Transitions and learning through the lifecourse. Routledge.

Ennerberg, E. (2020). Unemployment services for newly arrived migrants in Sweden: The privatization and rebureaucratization of the introduction programme. Social Policy and Administration, 54(5), 719-732. https://doi.org/10.1111/spol.12571.

Evans, K., \& Biasin, C. (2017). Exploring agency, learning and identity in women's life trajectories in UK and Italy. Revista Española de Educación Comparada, 29, 15-32. https://doi.org/10.5944/ reec.29.2017.17212.

Fejes, A., \& Nylander, E. (2019). Mapping out the research field of adult education and learning. https://ebookcentral.proquest.com/lib/usherbrookemgh-ebooks/detail.action?docID=5779950.

Fóti, K. (2019). The role of the EU in integrating asylum-seekers and refugees: limitations and opportunities. Transfer: European Review of Labour and Research, 25(1), 121-129. https://doi. org/10.1177/1024258919830059.

Gericke, D., Burmeister, A., Löwe, J., Deller, J., \& Pundt, L. (2018). How do refugees use their social capital for successful labor market integration? An exploratory analysis in Germany. Journal of Vocational Behavior, 105, 46-61. https://doi.org/10.1016/j.jvb.2017.12.002.

Giddens, A. (1991). Modernity and self-identity: Self and society in the late modern age. Polity Press.

Goodman, S. W. (2010). Integration requirements for integration's sake? Identifying, categorising and comparing civic integration policies. Journal of Ethnic and Migration Studies, 36(5), 753-772. https://doi.org/10.1080/13691831003764300.

Johnson, P., \& Zimmermann, K. F. (2008). Labour Markets in an Ageing Europe. Cambridge University Press.

Kvale, S. (2007). Doing interviews. Sage.

Lødemel, I., \& Moreira, A. (2014). Activation or workfare? Governance and the neo-liberal convergence. Oxford University Press.

Meidner, R. (1998). The rise and fall of the Swedish model. Challenge, 41(1), 69-90.

Mešić, N., Dahlstedt, M., Fejes, A., \& Nyström, S. (2019). Use-values for inclusion: Mobilizing resources in popular education for newly arrived refugees in Sweden. Social Inclusion. https://doi. org/10.17645/si.v7i2.1971.

Migrationsverket. (2019). Statistik. Antal Asylsökande - Aktuell Statistik. https://www.migrationsverke t.se/Om-Migrationsverket/Statistik.html.

Mouritsen, P., Faas, D., \& de Witte, N. (2019). Leitkultur debates as civic integration in North-Western Europe: The nationalism of 'values' and 'good citizenship. Ethnicities, 19(4), 632-653.

Morel, N., Palier, B., \& Palme, J. (2012). Towards a social investment welfare state? Ideas, policies and challenges. Policy Press.

Newman, A., Bimrose, J., Nielsen, I., \& Zacher, H. (2018). Vocational behavior of refugees: How do refugees seek employment, overcome work-related challenges, and navigate their careers? Journal of Vocational Behavior, 105, 1-5. https://doi.org/10.1016/j.jvb.2018.01.007.

Nicoll, K., \& Fejes, A. (2011). Lifelong learning: A pacification of 'know how. Studies in Philosophy and Education, 30(4), 403-417. https://doi.org/10.1007/s11217-011-9235-x.

Tavory, I., \& Timmermans, S. (2014). Abductive analysis: Theorizing qualitative research. The University of Chicago Press. 
Tomlinson, M. (2013). End games? Consumer-based learning in higher education and its implications for lifelong learning. Perspectives: Policy and Practice in Higher Education, 17(4), 124-128. https:// doi.org/10.1080/13603108.2013.832710.

Vetenskapsrådet. (2017). God Forskningssed [Good Research Practice]. https://www.vr.se/downl oad/18.2412c5311624176023d25b05/1555332112063/God-forskningssed_VR_2017.pdf.

Wikström, E., \& Ahnlund, P. (2018). Making refugees work? individualized work strategies in the Swedish refugee settlement program. Nordic Journal of Working Life Studies, 8(54), 47-65.

Yakushko, O., Backhaus, A., Watson, M., Ngaruiya, K., \& Gonzalez, J. (2008). Career development concerns of recent immigrants and refugees. Journal of Career Development, 34(4), 362-396. https:// doi.org/10.1177/0894845308316292.

Publisher's Note Springer Nature remains neutral with regard to jurisdictional claims in published maps and institutional affiliations. 